\title{
The Comparisons between Ethnicity and Poverty Level on Eight Graders'Science Performance
}

\author{
Hsin-Hui Lin, Ph. D. \\ School of Education and Human Development, University of Houston - Victoria \\ 3007 N. Ben Wilson, Victoria, TX 77901, United States \\ *Correspondence E-mail: linh@uhv.edu
}

Received: Nov. 11, 2014 Accepted: Nov. 22, 2014 Published: November 22, 2014

doi:10.5296/jse.v4i4.6600 URL: http://dx.doi.org/10.5296/jse.v4i4.6600

\begin{abstract}
The purposed of this study was to examine the relationships between ethnicity and poverty level with eight graders' science performance. This study utilized the $8^{\text {th }}$ grade data file (2006 - 2007) from the Early Childhood Longitudinal Study, Kindergarten Class of 1998-99 (ECLS-K) and had the sample size of 7,305 students. A full 2-way ANOVA model was applied to test the ethnicity and poverty level effects on the students' science performance. Results indicated that ethnicity and poverty had significant effects on students' science performance. White students have the highest mean score, followed by Asian, but African American students have the lowest mean scores. The gap on the mean scores between the highest and the lowest group was 20 points. White and Asian students do better on science performance, while Hispanic and African American students have lower scores. The impact among the interactions of ethnicity and poverty persisted within the breakdown of 10 subgroups' outcomes. The subgroup of Asian "at/above poverty" had the highest mean scores, while the subgroup African American "below poverty" had the lowest scores. Future studies should continue to investigate African American students in conjunction with science performance.
\end{abstract}

Keywords: Science, Science Performance, Science Assessment, Poverty, Ethnicity 


\section{Introduction}

The population of the U.S. public school system is constantly changing. There are about 50 million students and ethnic minority students accounted for $43 \%$. In 2006, 17\% of school-age children lived below the poverty level. In general, the ethnicity of the minority had a higher ratio of students who lived below poverty level. Thirty three percent of African American students and $26 \%$ of Hispanic students lived below the poverty level, but only $10 \%$ of white students (Planty, Hussar, Snyder, Provasnik, Kena, \& Dinkes, 2008).

\subsection{Poverty}

Between 1996 and 2005, research findings indicated that students from the above and below the poverty level performed differently on their science achievement (Grigg, Lauko, \& Brockway, 2006; O’Sullivan, Lauko, Grigg, Qian, \& Zhang, 2003). For example, the Third International Mathematics and Science Study (TIMSS), utilized the personal and school data from 13 year old participants, and found a strong correlation between science performance and poverty across 45 countries (Yang, 2003).

Compared to low poverty schools, high poverty schools had more novice teachers, fewer certified teachers, fewer resources, and inadequate laboratory facilities (Peske \& Haycock, 2006). Students' poverty level has been found to correlate with teachers' teaching quality. When students' poverty level increased, the level of teacher quality decreased (U. S. Department of Education, 2003).

In addition, high poverty schools tended to have more unmotivated students and lower teacher moral (Lynch, 2000). Not only children born into poverty lacked the same opportunities and resources to succeed as to more affluent students (Kahlenberg, 1995), but also many poor minority students were placed in the low track classes. Once when students become trapped in a subculture of poor performance and failure, the chance that allows these students to escape the hierarchical labels of tracking became rare (Gilbert \& Yerrick, 2001).

\subsection{Ethnicity}

Students' science performance differed by ethnicity. One earlier study showed that white students performed better than other ethnicities at ages nine, thirteen, and seventeen (Rakow, 1985). Another study, conducted in 1990, indicated Asian students had the highest science proficiency in the $12^{\text {th }}$ grade, but not in either $4^{\text {th }}$ or $8^{\text {th }}$ grades (National Science Foundation, 1994). In the year of 2000, there was a five percent increase in the population of students who lived below poverty level. Fourth grade Hispanic and African American students had narrowed the persistent gap with white students (Grigg, et al., 2006). A comparison was made on the fourth grade students' science performance by ethnicities. The finding showed that in order of highest to lowest, were white, Asian, Hispanic, and African American (U.S. Department of Education, 2007).

Recent studies found that white and Asian students constantly out performed Hispanic and African American students in science subjects. The difference among these students can be 
tracked as early as in the third grade (Kohlhaas, Lin, \& Chu, 2010) and fifth grade (Kohlhaas, Lin, \& Chu, 2010).

Although children begin school with the same attitudes towards science, but the ethnicity minority often becomes less prepared for science as students moved up to the upper grades (Peng \& Hill, 1995). The possible reasons were ethnicity minority students tend to have insufficient opportunities to learn with regards to the curriculum, quality of instruction, and the disconnection between students' schools, and homes and communities (Lee \& Luyks, 2005, 2007).

\section{Purpose of the study}

The purpose of this study was to compare the science performance between ethnicity and poverty level of eighth graders.

\section{Research method}

\subsection{Data file and samples}

The eighth grade ECLS-K data included students with learning disabilities who were not of interest in this study and might skew the estimates. After removing this group of students, there were 7,305 eighth grade students whose data and achievement scores in science were examined.

\subsection{Weights}

The ECLS-K used a multistage probability sample design to select a nationally representative sample of children attending kindergarten in 1998-99. Based on the recommendation made by the National Center for Education Statistics (NCES), the eighth grade "direct child assessment" weight of C7CW0 was applied in this study, so the results can be applied to the norm (Tourangeau, Nord, Lê, Sorongon, \& Najarian, 2009). Educators can use the results to interpret children's performance in the population and help students improve the science learning outcomes.

\subsection{Measures of independent variables}

Ethnicity. Students' ethnic data were not collected at eighth grade, but were verified through a composite of the parents' and teachers' surveys given in kindergarten, first and third grades. There were a total of seven ethnic groups defined by ECLS-K. In this study, the ethnicities were redefined into 5 groups in order to obtain larger sample sizes in the minority groups. The groups were: "1" White, "2" African American, "3" Hispanic, "4" Asian, and "5" Other.

Poverty. The ECLS-K defined the poverty levels through a weighted average income in combination with the size of the family unit, and the number of related children less than 18 years of age (U.S. Census Bureau, 2006). The variable was coded dichotomously, "1" below poverty and "2" at/above poverty.

\subsection{Measure of dependent variable}

Eighth graders' science performance was the dependent variable for this study. The ECLS-K used 111 science items that focused on conceptual understanding and scientific investigation 
frameworks to measure students' science performance. Based on the 1996 the National Assessment of Educational Progress (NAEP) frameworks, the content covered earth, physical, and life sciences. The ECLS-K collected students' science scores in raw score, t-score, and Item Response Theory (IRT) scale score. The Science (IRT) scale scores were used for this study.

\subsection{Statistical Analyses}

Chi-square test was conducted to test the independent distribution of the poverty levels within each ethnicity group. A full two-way analysis of variance (ANOVA) model was designed to test each of the two main effects (ethnicity and poverty) and the interaction effect (ethnicity $\mathrm{x}$ poverty). With five subgroups for ethnicity and two groups for poverty, the two-way ANOVA had a total of 10 breakdown groups.

\section{Results}

From the 7,305 eighth graders, 4, $516(62 \%)$ were white, $700(10 \%)$ were African American, 1,276 (18\%) were Hispanic, 427 (6\%) were Asian, and 377 (5\%) were Other. The "below poverty" group had 1,128 (15\%) students and "at/above poverty" group included 6,177 (85\%) of the students. Table 1 displays the sample size, mean, and standard deviation of eighth grade Science IRT scale scores before and after applying weight analyses.

Table 1. Descriptive Statistics of Eighth Grade Science IRT Scores by Ethnicity and Poverty

\begin{tabular}{|c|c|c|c|c|c|c|c|c|c|c|c|c|}
\hline \multirow[b]{2}{*}{ Variable } & \multirow[b]{2}{*}{$\mathrm{N}$} & \multirow[b]{2}{*}{$\%$} & \multicolumn{4}{|c|}{ Unweight } & \multirow[b]{2}{*}{ Max. } & \multicolumn{3}{|c|}{ Weighted } & \multirow[b]{2}{*}{ Min. } & \multirow[b]{2}{*}{ Max. } \\
\hline & & & M & SD & Rang & Min. & & M & SD & Range & & \\
\hline $\begin{array}{l}\text { All 8th } \\
\text { grade } \\
\text { students }\end{array}$ & 7305 & & 87 & 14.6 & & 30 & 108 & 85 & 15.8 & & 30 & 108 \\
\hline Gender: & & & & & & & & & & & & \\
\hline Male & 3554 & $49 \%$ & 88 & 14.8 & 78 & 28 & 108 & 87 & 15.7 & 78 & 30 & 108 \\
\hline Female & 3751 & $51 \%$ & 85 & 15.0 & 77 & 30 & 108 & 84 & 15.87 & 77 & 31 & 108 \\
\hline Ethnicity: & & & & & & & & & & & & \\
\hline White & 4516 & $62 \%$ & 91 & 11.7 & 75 & 28 & 108 & 90 & 12.4 & 75 & 28 & 108 \\
\hline $\begin{array}{l}\text { African } \\
\text { American }\end{array}$ & 700 & $10 \%$ & 73 & 16.1 & 74 & 31 & 108 & 70 & 16.87 & 74 & 31 & 105 \\
\hline Hispanic & 1276 & $18 \%$ & 80 & 16.5 & 78 & 30 & 108 & 79 & 16.58 & 78 & 30 & 108 \\
\hline Asian & 427 & $6 \%$ & 90 & 14.5 & 69 & 38 & 108 & 88 & 14.7 & 69 & 38 & 108 \\
\hline Other & 377 & $5 \%$ & 84 & 17.0 & 76 & 32 & 108 & 82 & 16.0 & 76 & 32 & 108 \\
\hline Poverty & & & & & 0 & & & & & 0 & & \\
\hline $\begin{array}{l}\text { Below } \\
\text { poverty }\end{array}$ & 1128 & $15 \%$ & 74 & 16.9 & 78 & 30 & 108 & 72 & 17.4 & 78 & 28 & 108 \\
\hline $\begin{array}{l}\text { At/above } \\
\text { poverty }\end{array}$ & 6177 & $85 \%$ & 89 & 13.1 & 76 & 32 & 108 & 88 & 14.3 & 76 & 31 & 108 \\
\hline
\end{tabular}


A chi-square test was conducted to examine the independent distribution, because small or uneven sample sizes could decrease the power of analysis. Therefore, it was important to check the independent distribution of poverty levels and ethnicity groups. The chi-square test was statistically significant, $X^{2}=877.50, d f(4), p<.001$.

A two-way ANOVA test was conducted to test the main and interaction effects among poverty and ethnicity on the eighth grade science performance. Table 2 displays the degree of freedom, $F$ value, and $p$ value. All of the significant tests had satisfactory power and all of the $F$ values were significant $(p<0.001)$. This means that independently and interactively the two variables, poverty and ethnicity, had significant effects on students' science performance.

Table 2. Two-way ANOVA Test the Effects of Ethnicity and Poverty on Students' Science Performance

\begin{tabular}{lrrrrr}
\multicolumn{1}{c}{ Type III Sum of } & & & & \multicolumn{1}{c}{ F } & \multicolumn{1}{c}{ Sig. } \\
\hline Source & \multicolumn{1}{c}{ Squares } & df & Mean Square & 0.000 \\
Ethnicity & 71725556.27 & 4 & 17931389.07 & 96340.61 & 0.000 \\
Poverty & 26754979.97 & 1 & 26754979.97 & 143747.44 & 0.000 \\
Ethnicity *Poverty & 1170514.65 & 4 & 292628.66 & 1572.22 & \\
Error & 518833635.94 & 2787556 & 186.12 & & \\
Total & 20617679025.81 & 2787566 & & & \\
Corrected Total & 735063681.33 & 2787565 & & & \\
\hline
\end{tabular}

a. R Squared $=.294($ Adjusted R Squared $=.294)$

b. Computed using alpha $=.05$

The average weighted eighth grade Science IRT scale score for all the students was 85 with a standard deviation of 15.8 and a range from 30 to 108. The mean scores for the white was 90 , African American was 70, Hispanic was 79, Asian was 88, and Other was 82 (see Table 1). The main effect of ethnicity on the ANOVA test showed statistical significance, [F (4, $2787566)=96340.61, p<.001]($ see Table 2$)$.

The "below poverty" students had a mean science score of 72 and the "at/above poverty" group had a mean score of 88 . The comparison of poverty was statistically significant [F (1, $2787566)=143747.44, p<.001]($ see Table 2$)$.

The interaction effect on eighth grade science performance was significant. Ten (5X2) subgroups were analyzed and the results of mean scores were as follows: white "below poverty" $(\mathrm{M}=81)$ and white "at/above poverty" $(\mathrm{M}=91)$, African American "below poverty" $(\mathrm{M}=63)$ and African American "at/above poverty" $(\mathrm{M}=74)$, Hispanic "below poverty" $(\mathrm{M}=72)$ and Hispanic "at/above poverty" $(\mathrm{M}=83)$, Asian "below poverty" $(\mathrm{M}=$ $76)$ and Asian "at/above poverty" $(\mathrm{M}=92)$, finally Other "below poverty" $(\mathrm{M}=70)$ and Other "at/above poverty" $(\mathrm{M}=86)$ (see table 3$)$. The ANOVA test of the interaction effect of ethnicity and poverty reached statistical significance, $[F(4,2787566)=1572.22, p<.001]$ (see Table 2). 
Table 3. Two-Way Breakdowns of Eighth Grade Science IRT Scores

\begin{tabular}{lcc} 
Ethnicity & Below Poverty & At/above Poverty \\
\hline White & 81 & 91 \\
African American & 63 & 74 \\
Hispanic & 72 & 83 \\
Asian & 76 & 92 \\
Other & 70 & 86 \\
\hline
\end{tabular}

\section{Discussion}

This study utilized the ECLS-K, a large-scale national database, to investigate ethnicity and poverty level on eighth graders' science outcomes. The ECLS-K database allowed the examination of ethnicity and poverty simultaneously with acceptable power in all the tests. The disaggregated data provides insights that allow educators to compare eighth graders' science performance in regard to their poverty and ethnicity background. The level of disaggregated report of this study had two independent variables (main effect and the interaction effect). Regardless of reorganizing students into increasingly smaller, more well-defined subgroups, all tests showed statistical significance at $p<.001$ level.

When investigating the ethnicity main effect on the eighth graders' science assessment, white students have the highest mean score, followed by Asian, but African American students have the lowest mean scores. The gap on the mean scores between the highest and the lowest group was 20 points. White and Asian students do better on science performance, while Hispanic and African American students have lower scores.

It is not surprising that students from at/above poverty performed better than the below poverty counterparts. The difference between the at/above and the below poverty group was 16 points. The two way interaction tests revealed that students of each ethnicity group, the at/above group performed better than the below group. For example, white at/above poverty did better than the white below poverty group. When comparing the 10 subgroups, Asian "at/above poverty" students had the highest science mean scores, white "at/above poverty" students were the second highest group with only one point less than the previous group. African American "below poverty" students had the lowest on science performance among the 10 subgroups. In addition, the white and Asian "below poverty" groups had higher science scores than the African American "at/above poverty" students (see figure 1). 


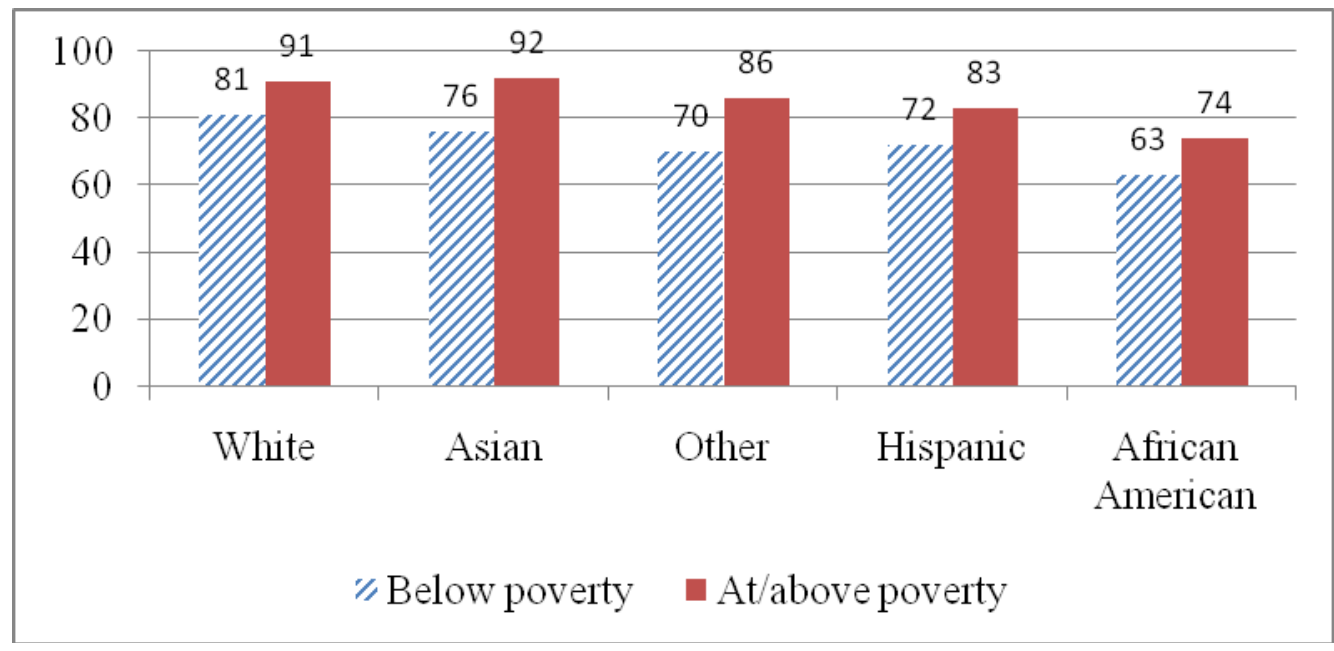

Figure 1. Eighth Grade Science IRT Scores by Poverty and Ethnicity

This study found that within the "at/above poverty" group, Asian students did score one point better than white students on the science performance. However, the white "below poverty" group had five points higher than their Asian counterparts.

In addition, this study revealed that ethnicity and poverty had some effects on students' science performance. The impact among the interactions of ethnicity and poverty persisted within the breakdown of the 10 subgroups' outcomes.

\section{Future Studies}

Future studies should continue to investigate African American students in conjunction with science performance. It is not clear why African Americans performed less than the other counterparts. Close monitoring of African American students on their science learning progress, students' in-depth interviews, and the science learning experience are necessary to further explore possible barriers. Early intervention programs are needed to and should reach out to below poverty level students.

\section{References}

Gilbert, A., \& Yerrick, R. (2001). Same school, separate worlds: A sociocultural study of identity resistance, and negotiation in a rural, lower track science classroom. Journal of Research in Science Teaching, 38(5), 574-598. http://dx.doi.org/10.1002/tea.1019

Grigg, W., Lauko, M., \& Brockway, D. (2006). The nation's report card science 2005: Assessment of student performance in grades 4, 8, and 12 (NCES 2006-466). U.S. Department of Education Statistics. Washington, DC: U.S. Government Printing Office. $\begin{array}{llll}\text { Retrieved November } & \text { 17, } & 2014 & \text { from }\end{array}$ http://nces.ed.gov/nationsreportcard/pdf/main2005/2006466.pdf

http://nces.ed.gov/nationsreportcard/pubs/main2005/2006466.asp\#pdflist

Kohlhaas, K., Lin, H. H., \& Chu, K. (2010). Science equity in third grade. Elementary School Journal, 110(3), 393-408. http://dx.doi.org/10.1086/648985 
Kohlhaas, K., Lin, H. H., \& Chu, K. (2010). Disaggregated outcomes of ethnicity, gender, and poverty on fifth grade science performance. Research in Middle Level Education Online 33(6), 1-12. Retrieved November 17, 2014 from http://files.eric.ed.gov/fulltext/EJ887821.pdf

Kahlenberg, R. D. (1995a) Class, not race. The New Republic, 212(14), 21-27.

Lee, O., \&Luykx, A. (2005). Science education and student diversity: Synthesis and research agenda. Journal of Education for Students Place at Risk, 10(4), 433-440. http://dx.doi.org/10.1207/s15327671espr1004_5

Lee, O., \&Luykx, A. (2007). Science education and student diversity: Race/ethnicity, language, culture, and socioeconomic status. In S. K. Abell\& N. G. Lederman (Eds.), Handbook of Research on Science Education, (pp. 171-197). Mahwah, NJ: Lawrence Erlbaum Associates, Inc.

Lynch, S. (2000). Equity and science education reform. Mahwah, NJ: Lawrence Erlbaum Associates, Inc.

National Science Foundation (1994).Women, minorities, and persons with disabilities in science and engineering: 1994. (NSF 94-33) Arlington, VA. Retrieved November 17, 2014 from http://www.nsf.gov/statistics/wmpdse94/

O’Sullivan, C. Y., Lauko, M. A., Grigg, W. S., Qian, J., \& Zhang, J. (2003). The nation's report card: Science 2000 (NCES 2003-453). Washington, DC: U.S. Department of Education, Institute of Education Sciences. Retrieved November 17, 2014 from http://nces.ed.gov/pubsearch/pubsinfo.asp?pubid=2003453

Peng, S. S., \& Hill, S.T. (1995). Understanding racial-ethnic differences in secondary school science and mathematics achievement. National Center for Education Statistics: Research and Development Report.

Peske, H.G. \& Haycock, K. (2006). Teaching inequality: How poor and minority students are shortchanged on teacher quality. The Education Trust. Retrieved March 16, 2007 from http://files.eric.ed.gov/fulltext/ED494820.pdf

Planty, M., Hussar, W., Snyder, T., Provasnik, S., Kena, G., Dinkes, R., (2008).The Condition of education 2008, (NCES 2008-031). National Center for Education Statistics, Institute of Education Sciences, U. S. Department of Education, Washington, DC. Retrieved November 17, 2014 from http://nces.ed.gov/pubsearch/pubsinfo.asp?pubid=2008031

Rakow, S. J., (1985). Minority students in science: Perspectives from the 1981-1982 National Assessment in Science. Urban Education, 20(1), 103-113. http://dx.doi.org/10.1177/004208598502000107

Tourangeau, K., Nord, C., Lê, T., Sorongon, A. \& Najarian, M. (2009). Early childhood longitudinal study, kindergarten class of 1998-99 (ECLS-K): Combined user's manual for the ECLS-K eighth-grade and K-8 full sample data files and electronic codebooks (NCES 2009-004). U.S. Department of Education. Washington, DC: National Center for Education Statistics. Retrieved August 15, 2014 from http://files.eric.ed.gov/fulltext/ED511826.pdf 
U.S. Census Bureau. (2006). Poverty thresholds 2006. Retrieved August 10, 2014 from https://www.census.gov/hhes/www/poverty/data/threshld/thresh06.html

U. S. Department of Education, National Center for Education Statistics (2003). The condition of education 2003 (NCES 2003-067), U. S. Government Printing Office, Washington, DC. Retrieved November 17, 2014 from http://www.gpo.gov/fdsys/pkg/ERIC-ED479294/pdf/ERIC-ED479294.pdf

U.S. Department of Education. (2007). The condition of education 2007: Science performance of students in grades 4, 8, and 12 (NCES 2007-064), U.S. Government Printing Office, Washington, DC. Retrieved November 17, 2014 from http://nces.ed.gov/pubs2007/2007064_2.pdf

Planty, M., Hussar, W., Snyder, T., Provasnik, S., Kena, G., Dinkes, R., (2008).The Condition of education 2008, (NCES 2008-031). National Center for Education Statistics, Institute of Education Sciences, U. S. Department of Education, Washington, DC.

Rakow, S. J., (1985). Minority students in science: Perspectives from the 1981-1982 National Assessment in Science. Urban Education, 20(1), 103-113.

Tourangeau, K., Nord, C., Lê, T., Sorongon, A. \&Najarian, M. (2009).Early childhood longitudinal study, kindergarten class of 1998-99 (ECLS-K): Combined user's manual for the ECLS-K eighth-grade and K-8 full sample data files and electronic codebooks (NCES 2009-004). U.S. Department of Education. Washington, DC: National Center for Education $\begin{array}{lllll}\text { Statistics. } & \text { Retrieved } & \text { August } & 15, & \text { from }\end{array}$ http://nces.ed.gov/ecls/data/ECLSK_K8_Manual_part1.pdf.

U.S. Census Bureau. (2006). Poverty thresholds 2006. Retrieved August 10, 2014 from https://www.census.gov/hhes/www/poverty/data/threshld/thresh06.html

U. S. Department of Education, National Center for Education Statistics (2003). The condition of education 2003 (NCES 2003-067), U. S. Government Printing Office, Washington, DC.

U.S. Department of Education. (2007). The condition of education 2007: Science performance of students in grades 4, 8, and 12 (NCES 2007-064), U.S. Government Printing Office, Washington, DC. 